\title{
Effect of Loan Portfolio Characteristics on the Level of Non-performing Loans for Savings and Credit Co-operative Societies in Kirinyaga County Kenya
}

\author{
James Muchiri Ndambiri ${ }^{1}$, Everlyn Ninga Munene ${ }^{1}$, Stephen Muthii Wanjohi ${ }^{2}$ \\ ${ }^{1}$ Muchiri Ndambiri and Company Consulting Group (MNC), Nairobi, Kenya \\ ${ }^{2}$ Department Statistics and Actuarial Science, Jomo Kenyatta University of Agriculture and Technology, Nairobi, Kenya
}

Email address:

muchiri@jamesndambiri.me.ke (J. M. Ndambiri), eve@mncconsulting.co.ke (E. N. Muchiri), wanjohi8280@yahoo.com (S. M. Wanjohi)

To cite this article:

James Muchiri Ndambiri, Eve.lyn Ninga Muchiri, Stephen Muthii Wanjohi. Effect of Loan Portfolio Characteristics on the Level of Nonperforming Loans for Savings and Credit Co-operative Societies in Kirinyaga County Kenya. International Journal of Finance and Banking Research. Vol. 3, No. 5, 2017, pp. 58-69. doi: 10.11648/j.ijfbr.20170305.11

Received: April 18, 2017; Accepted: June 16, 2017; Published: November 10, 2017

\begin{abstract}
The main source of income for Savings and Credit Co-operative Societies in Kenya is from interest received from issue of loans to its members. However the issuance of loans has been faced with a lot of challenges as a result of default on repayment of principal loan and interest when they fall due. In the event that this trend is not checked it could lead to collapse of Savings and Credit Co-operative Societies movement and hence have a negative impact on the financial sector. The main objective of the study was to determine the effect of loan portfolio characteristics on the level of Non-Performing Loans for Savings and Credit Co-operative Societies in Kirinyaga County. The study was conducted on Deposit Taking Savings and Credit Co-operative Societies in Kirinyaga County, Kenya. The researcher used both descriptive and causal research design. The Deposit Taking Savings and Credit Co-operative Societies registered by Savings and Credit Co-operative Societies Regulatory Authority for the period 2011-2014 in Kirinyaga County were six and hence a census was conducted. The researcher used secondary data which was obtained from published Savings and Credit Co-operative Societies Annual Financial Statements and Reports and from Savings and Credit Co-operative Societies Supervision Annual Reports for the period 2011-2014 with data collection checklist being used as the instrument for data collection of the models. The findings of the study would be helpful to current and potential investors, regulatory bodies and would add important information to the existing body of literature. The study recommended that Savings and Credit Co-operative Societies should diversify their loan portfolio by advancing loan of different products, consider adjusting loans repayment period appropriately, should not concentrate much on making decisions on interest rates adjustment, ensure that the ratio of Loan to Shareholder equity is high so that they can have a strong asset base thus win public confidence and should consider advancing loans of different amounts since borrowers vary in their credit worthiness.
\end{abstract}

Keywords: Loan Portfolio, Loan Tenure, Sacco, Credit Worthiness

\section{Introduction}

\subsection{Background of the Study}

A Non-Performing Loan (NPL) is a credit facility in respect of which the interest and or principal amount has remained past due for a specific period of time. According to [27] Non-Performing Loans (NPLs) are those loans which are ninety days or more past due and no longer accruing interest. [29] Agrees that non-performing loans are those loans which are not generating income. [40] Observes that NPLs in loan portfolio affect operational efficiency which in turn affects profitability, liquidity and solvency position of banks. [4] Notes that in addition to the influence on profitability, liquidity and competitive functioning, NPLs also affect the psychology of bankers in respect of their disposition of funds towards credit delivery and credit expansion. NPLs generate a vicious effect on banking survival and growth, and if not managed properly leads to banking failures. 
[9] A Loan portfolio is the total of all loans held by a bank, or finance company on any given day. In this regard, different loan products in SACCOs form a loan portfolio. Loan portfolio size depends on the size and capacity of the borrowers which is also influenced by their economic status in that particular location [26] asserted that loan portfolio management is the process by which risks that are inherent in the credit process are managed and controlled. [60] Described credit portfolio management as the process of building a series of investments based upon credit relationships and managing the risks involved with these investments. The main purpose of portfolio management is to reduce the amount of loans default. SACCOs reduce the loan portfolio default risk by considering the credits repayment history of both individuals and groups applying for loans. This strategy also might be applied by other financial institutions to screen qualified clients applying for loans. Thus a SACCO will have effective loan portfolio management if it has effective management system and procedures. [26] Stated that effective loan portfolio management function is vital for maintaining the Sacco's safety and soundness. SACCOs should design the stress testing measures to examine the vulnerability of portfolios loss due to unanticipated events. Effective portfolio management also might foster the performance and sustainability of SACCOs. Consequently, it will reduce the level of NPLs.

\subsection{Statement of the Problem}

The main objective of SACCOs is to accumulate savings and lend out to members at a lower interest rate compared to the market. SACCOs issue loans of different types to its members. The major source of income for SACCOs arises from interest from their loan portfolio. The quality of loan portfolio held by a SACCO may affect its level of NPLs and thus its overall profitability. Failure to contain NPLs in a financial institution may lead to reduced profitability, reduced shareholders wealth, loss in tax revenue to the government and in worst case, collapse of the entire sector. Previous studies have focused on the effect of credit analysis, quality of portfolio, risk management and market diversification on the level of NPLs. This study endeavored to determine the effect of loan portfolio characteristics on the level of NPLs for SACCOs in Kirinyaga County by examining the effect of portfolio diversification, loan pricing, loan tenure, loan to shareholders equity and size of loan portfolio on the level of NPLs for SACCOs.

\subsection{General Objective}

The general objective of the study was to determine the effect of loan portfolio characteristics on the level of NonPerforming Loans for Savings and Credit Co- operative Societies in Kirinyaga County, Kenya.

\subsection{Specific Objectives}

The study was guided by the following specific objectives: a) To determine the effect of loan portfolio diversification on the level of Non- Performing Loans for Savings and Credit Co-operative Societies in Kirinyaga County, Kenya.

b) To determine the effect of loan pricing on the level of Non-Performing Loans for Savings and Credit Cooperative Societies in Kirinyaga County, Kenya.

c) To determine the effect of loan tenure on the level of Non-Performing Loans for Savings and Credit Cooperative Societies in Kirinyaga County, Kenya.

d) To determine the effect of loan to shareholders' equity on the level of Non- Performing Loans for Savings and Credit Co-operative Societies in Kirinyaga County, Kenya.

e) To determine the effect of size of loan on the level of Non-Performing Loans for Savings and Credit Cooperative Societies in Kirinyaga County, Kenya.

\subsection{Research Hypotheses}

The study tested the following hypothesis:

$\mathrm{H}_{01}$ : here is no significant relationship between loan portfolio diversification and the level of Non-Performing Loans for Savings and Credit Co-operative Societies in Kirinyaga County, Kenya.

$\mathrm{H}_{02}$ : There is no significant relationship between loan pricing and the level of Non- Performing Loans for Savings and Credit Co-operative Societies in Kirinyaga County, Kenya.

$\mathrm{H}_{03}$ : There is no significant relationship between loan tenure and the level of Non- Performing Loans for Savings and Credit Co-operative Societies in Kirinyaga County, Kenya.

$\mathrm{H}_{04}$ : There is no significant relationship between loan to shareholders' equity and the level f Non-Performing Loans for Savings and Credit Co-operative Societies in Kirinyaga County, Kenya.

$\mathrm{H}_{05}$ : There is no significant relationship between size of loan and the level of Non- Performing Loans for Savings and Credit Co-operative Societies in Kirinyaga County, Kenya.

\subsection{Significance of the Study}

This research provides important information that would help current investors evaluate the quality of their investment and know whether to hold on or rebalance their investment portfolio accordingly and also assist potential investors make their decision on whether to invest in the SACCOs or not.

The findings of this report would help SASRA in formulating effective strategies and policies to curb the negative effect of NPLs thus enhance sustainability of SACCO movement in Kenya.

\section{Literature Review}

\subsection{Empirical Review}

The study of NPLs and their determinants in financial institutions has greatly increased in recent years. Several 
studies have been conducted on NPLs and default rate. Findings from the studies have provided insight on the quality of loan portfolios and generally the fragility of financial institutions.

[5] Conducted a study on the effect of NPLs on financial performance. The study involved a regression analysis of NPLs as independent variable and operational costs as the dependent variable. The study reveals that the level of NPLs is a significant determinant of the bank costs as well as the estimates of scale economies in banking. His study further reveals that the cost curves of banks with high levels of NPLs have the standard U-shape with the optimal point while on the other hand banks with low levels of NPLs do not exhibit the same characteristics. Their cost curves show that scale economies increase continuously with the bank size.

[24] Surveyed on operating efficiency and loan portfolio indicators usage by microfinance institutions found out that most microfinance institutions to a great extent used operating efficiency indicator as a credit risk management practice. Efficiency and productivity ratios are used to determine how well microfinance institutions streamline their credit operations. He also noted that microfinance institutions need to employ a combination of performance indicators such as profitability, operating efficiency and portfolio quality to measure their overall performance.

[1] Report that diversification of a bank assets is not guaranteed to produce superior performance or greater safety for banks for a sample of 105 Italian banks.[1] Examined the effects of diversification on market value of large banks from 42 countries and found that market value of diversified banks were lower than those of their specialized counterparts. [13] Show that better diversification does not translate into reduction in overall risk. [34] Concur with these findings. [30] Find that increased diversification leads to lower equity and accounting returns for all banks. This result is consistent with evidence provided by several studies of [15].

[36] Contacted a survey on risk based capital standards and the riskiness of bank portfolio in Kenya and indicated that there is a clear indication there must be a cost on credit portfolio management and if not well controlled at inception, then a crisis must be anticipated. He recommended that training staff and getting the certified credit risk management could be healthy in management of credit portfolio.

\subsection{Theoretical Review}

\subsubsection{Modern Portfolio Theory}

This theory states that securities should be chosen on the basis of how they interact with one another rather than how they perform in isolation [37]. According to this theory an optimal combination would secure for the investors the highest possible return for a given level of risk or the least possible risk for a given level of return. Portfolio theory is presented in mathematical formulation and clearly gives the idea of diversifying the asset investment combination with the aim of selecting the combination of assets that will yield the highest return at a given level of risk. For risk diversification purposes a negative relationship is recommended. The investor must therefore measure the correlation of returns of his assets. Security returns are assumed to have a negative relationship if a given economic factor affects their performance in the opposite direction. However, according to [46] risk diversification lowers the level of risk even if the assets returns are not negatively related. The risk due to NPLs was measured by use of standard deviation. When different assets are combined and whose returns are not perfectly positively correlated then portfolio theory leads to reduction of the total variance of such asset Combination over the given period of investments.

It was noted that the level of risk and NPLs in a portfolio depended on risk of each loan proportion of resources allocated on each loan and the nature of relationship between the returns of the loans forming the portfolio. The major assumption of portfolio theory in managing risk are that the investors are rational hence prefer more to less, investors are risk averse, it ignores risk of bankruptcy which investors face when they borrow in order to make investments and assume that the market is perfect and efficient [12].

\subsubsection{The Capital Asset Pricing Model (CAPM) Theory}

The development of CAPM has been a major achievement in financial decision platform especially in asset pricing and makes it more possible in quantification and pricing. CAPM is a model that provides a framework that determines the required rate of return (RRR) on an asset and indicates the relationship between returns and risk of the asset. This relationship is very useful in two important ways. First it produces a benchmark for evaluating various projects and secondly it helps us to make an informed guess about the return that can be expected from assets that have not yet been traded or issued in the market.

[37] business/operations/total risk refers to fluctuations of the company's expected earnings due to the nature of the industry in which the company operates. Business risk is a combination of systematic and unsystematic risk.

Systematic/un-diversifiable risk refers to variations in returns of securities due to factors which systematically affect all firms adversely e. g. Inflation, war, recession and interest rates among others. They are usually the variations of assets value as a result of unpredictable macro factors movements in the business environment set up. Systematic risk are a must adopt by the investors as they are inherent therefore necessitating their adoption. According to [22] the risk associated with an asset is measured in relation to the market risk. The best performance is the one which is able to outdo the market.

Unsystematic/diversifiable risk refers to variations in return of a company due to factors which are unique to a specific company for example legal suits, strikes, losing or winning of a major contract, successful or unsuccessful marketing program and many others. Since these events are essentially random, then their effects on a portfolio can be eliminated by diversification where bad event in one product can be offset by another one. Unsystematic risk represents that component of assets return which is uncorrelated with 
the general market movement [24] It can therefore be diversified and it will always depend on the institutions approach. Different organizations have different specific risks whose total output may differ depending on how they approach them in form of the assets, ideas, policies and personnel among others [22].

\subsubsection{Arbitrage Pricing Theory (APT)}

The initial empirical study of APT was done by [8] in which he concluded that two risk factors must represent return as opposed to a single factor of CAPM. However [23] did the first publication in which he carried out similar version of factor analysis approach. There weren't any further studies until [49] carried out their own empirical investigation on APT. Like CAPM, APT is a linear model though with multiple beta rather than single beta as in CAPM [11] APT is based on the assumption and insights developed in CAPM and Efficient Market Hypothesis (EMH).

The APT is an asset pricing originally developed by [49] it is founded on the notion that investors are rewarded for assuming non-diversifiable (systematic) risk. Its development was as a result of weakness in the CAPM inability to account for the difference in asset's return using their betas. APT holds that the expected return of a financial asset can be modeled as a linear function of various macro-economic factor or theoretical market indices such as industrial production, growth in gross domestic product, interest rate, inflation, default premium and the real rate of return where sensitivity to changes in each factor is represented by a factor specific beta coefficient.

\subsection{Conceptual Framework}

The Conceptual framework is a plan of ideas (variables) which the investigator operationalizes so as to accomplish the set goals, [42]. A variable is a measure that accepts diverse qualities among subject, [42] Independent variables are the variables that a scientist controls so as to focus its impact on an alternate variable. [32] State that independent variable additionally termed as informative or explanatory variable is the assumed change in the reason for progressions in the word variable; the word variable endeavours to demonstrate the aggregate impact emerging from the impact of the autonomous variable [42]. The conceptual framework for this study is presented in figure 1 .

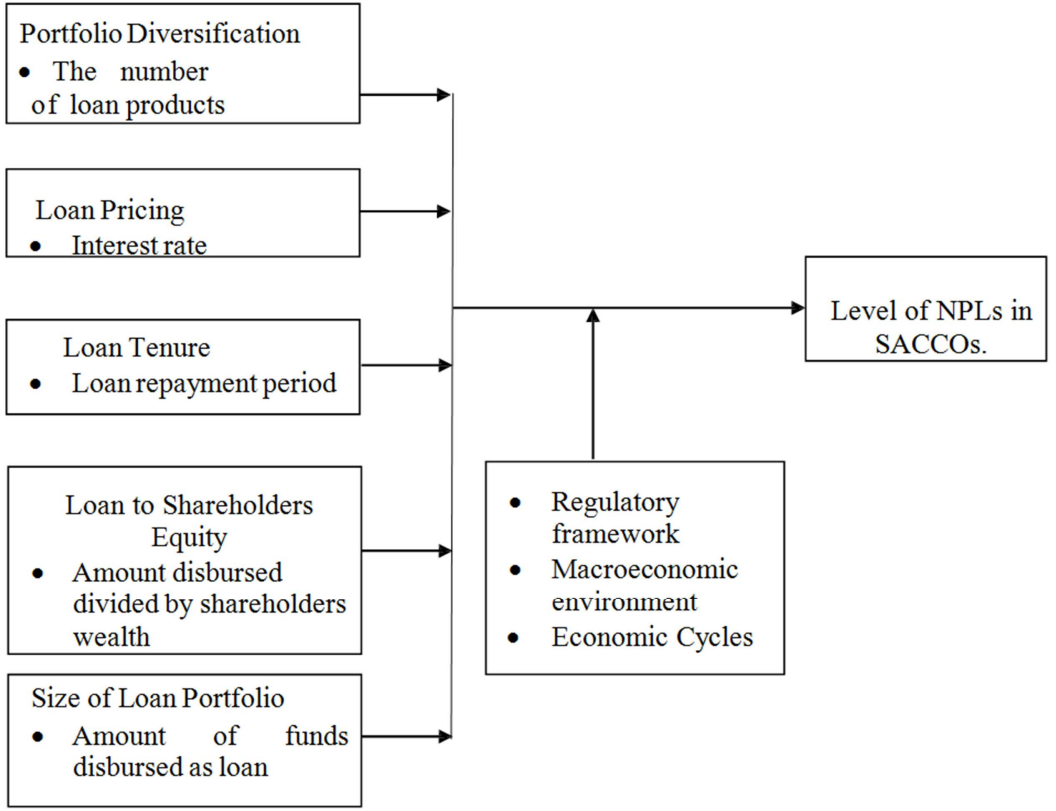

Independent Variables Intervening Variables Dependent Variables

Figure 1. Loan Portfolio Characteristics and the Level of NPLs in SACCOS.

\section{Research Methodology}

\subsection{Population of the Study}

The population of study was 6 SACCOs operating FOSA in Kirinyaga County which had been in operation from year 2011 to 2014. According to SASRA public notice on deposit taking SACCO Society for year 2014, there were 21 SACCOs in Kirinyaga County, out of which only 6 were licensed to operate FOSAs by year 2014.

\subsection{Econometric Model}

The variables in the study were related using scholastic Simple and multiple linear regression models as follows;

Model Specification for Objective One: To determine effect of loan portfolio diversification on the level of NPLs for SACCOs.

$$
\mathrm{Y}_{\mathrm{i}}=\beta_{0}+\beta_{1} \mathrm{D}+\varepsilon_{\mathrm{i}}
$$

Where: 
$Y_{i}=$ Average level of NPLs for period ì. $\beta_{0}=$ Constant term.

$\beta_{1}=$ Slope coefficient for loan portfolio diversification. $\mathrm{D}=$ Number of the loan products.

$$
\varepsilon_{\mathrm{i}}=\text { Error term. }
$$

Model Specification for Objective Two: To determine the effect of loan pricing on the level of NPLs for SACCOs.

$$
\mathrm{Y}_{\mathrm{i}}=\beta_{0}+\beta_{1} \mathrm{I}_{1}+\beta_{2} \mathrm{I}_{2}+\beta_{3} \mathrm{I}_{3}+\beta_{4} \mathrm{I}_{4}+\beta_{5} \mathrm{I}_{5}+\varepsilon_{\mathrm{i}}
$$

$Y_{i}=$ Average Level of NPLs for period i. $\beta_{0}=$ Constant term.

$\beta_{1}, \beta_{2} \ldots . \beta_{5}=$ Slope coefficients for loan pricing.

$\mathrm{I} 1=$ Amount loans advanced at a rate in the range of $0-12 \%$ p.a I2 = Amount loans advanced at a rate in the range of $13-18 \%$ p.a I3 = Amount loans advanced at a rate in the range of $19-36 \%$ p.a I4= Amount loans advanced at a rate in the range of $37-120 \%$ p.a I5= Amount loans advanced at a rate above $120 \%$ p.a

$$
\varepsilon_{\mathrm{i}}=\text { Error Term }
$$

Model Specification for Objective Three: To determine the effect of loan tenure on the level NPLs for SACCOs

$$
Y_{i}=\beta_{0}+\beta_{1} T_{1}+\beta_{2} T_{2}+\beta_{3} T_{3}+\beta_{4} T_{4}+\beta_{5} T_{5}+\varepsilon_{i}
$$

Where:

$Y_{i}=$ Average Level of NPLs for period i. $\beta_{0}=$ Constant term.

$\beta_{1}, \beta_{2} \ldots \beta_{5}=$ Slope coefficients for loan tenure. $T_{1}=$ Average loans with a tenure of $0-12$ months. $\mathrm{T}_{2}=$ Average loans with a tenure of 13-24 months. $\mathrm{T}_{3}=$ Average loans with a tenure of 25-48 months. $\mathrm{T}_{4}=$ Average loans with a tenure of 49-60 months. $\mathrm{T}_{5}=$ Average Loans with Tenure above 60 months. $\varepsilon_{\mathrm{i}}=$ Error Term.

Model Specification for Objective Four: To determine the effect of loan to shareholders' equity on the level of NPLs for SACCOs.

$$
\mathrm{Y}_{\mathrm{i}}=\beta_{0}+\beta_{1} \mathrm{E}+\varepsilon_{\mathrm{i}}
$$

Where:

$Y_{i}=$ Average Level of NPLs for period ì. $\beta_{0}=$ Constant term.

$\beta_{1}=$ Slope coefficient for loan to shareholders' equity.

$E=$ Average Loan to Shareholders equity for year 2011-2014

$$
\varepsilon_{\mathrm{i}}=\text { Error Term. }
$$

Model Specification for Objective Five: To determine the effect of size of loan on the level of NPLs for SACCOs.

$$
Y_{i}=\beta_{0}+\beta_{1} S_{1}+\beta_{2} S_{2}+\beta_{3} S_{3}+\beta_{4} S_{4}+\beta_{5} S_{5}+\varepsilon
$$

Where:

$Y_{i}=$ Average Level of NPLs for period ì $\beta 0=$ Constant term.

$\beta_{1}, \beta_{2} \ldots \beta_{5}=$ Slope coefficients for independent variables. $\mathrm{S}_{1}=$ Average loan size in the range Ksh (0-100,000).

$\mathrm{S}_{2}=$ Average loan size in the range Ksh $(100,001-250,000)$. $\mathrm{S}_{3}=$ Average loan size in the range Ksh $(250,001-500,000)$. $\mathrm{S}_{4}=$ Average loan size in the range Ksh $(500,001-1,000,000)$. $\mathrm{S}_{5}=$ Average loan size above Ksh 1,000,000.

$$
\varepsilon_{\mathrm{i}}=\text { Error Term. }
$$

Table 1. Data Analysis Matrix.

\begin{tabular}{l|l|l}
\hline Hypothesis & Independen Variables & Dependent Variables \\
\hline $\begin{array}{l}\text { H01: There is no significant relationship between loan portfolio } \\
\text { diversification and the level of NPLs for SACCOs }\end{array}$ & Portfolio Diversification & Level of NPLs \\
$\begin{array}{l}\text { H02: There is no significant relationship between loan pricing and the } \\
\text { level of NPLs for SACCOs }\end{array}$ & Loan Pricing & Level of NPLs \\
$\begin{array}{l}\text { H03: There is no significant relationship between loan tenure and the } \\
\text { level of NPLs for SACCOs }\end{array}$ & Loan Tenure & Level of NPLs \\
$\begin{array}{l}\text { H04: There is no significant relationship between loans to } \\
\text { shareholders equity and the level of NPLs for SACCOs } \\
\text { H05: There is no significant relationship between size of loan } \\
\text { portfolio and the level of NPLs for SACCOs }\end{array}$ & Loan to Shareholders Equity & Level of NPLs \\
\hline
\end{tabular}

\section{Results and Discussions}

\subsection{Loan Portfolio Diversification and the Level of NPLs for SACCOs.}

The study sought to establish the strength and magnitude of the relationship between Loan Diversification and the level of NPLs. The results are indicated in Table 2. The cause-effect relationship between Loan Diversification and the Level of NPLs was also analyzed and the results are indicated in Table 8.

Table 2. Test for significant of the Model for Objective One.

\begin{tabular}{llllll}
\hline $\mathbf{R}$ & \multirow{2}{*}{$\mathbf{R}^{2}$} & Adjust $\mathbf{R}^{2}$ & Std. Error of the Estimate & \multicolumn{2}{l}{ Change Statistics } \\
\cline { 3 - 6 } & 0.361 & 0.303 & 8.974 & R Square Change & F Change \\
\hline 0.601 & 0.361 & 0.214 & 0.030 \\
\hline
\end{tabular}

Predictors: (Constant), Loan Diversification.

Dependent Variable: Non-Performing Loans. 
Table 2 indicates that the correlation coefficient $(\mathrm{R})$, is 0.601 indicating that there was a positive moderate correlation between the Loan Diversification and the NPLs. The $\left(\mathrm{R}_{2}\right)$ was 0.361 implying that $36.1 \%$ of the variation in the level of NPLs was explained by the Loan Diversification while $63.9 \%$ were explained by other factors outside the model. From the results of simple linear regression analysis, it was found that the overall model was significant $(F=6.214$, $\mathrm{p}=0.030<0.05)$. Thus, the null hypothesis that Loan Portfolio Diversification has no significance effect on the level of NPLs was rejected.

Table 3. Loans Portfolio Diversification and Level of NPLs Statistics.

\begin{tabular}{lllll}
\hline \multirow{2}{*}{ Variables } & \multicolumn{2}{c}{ Unstandardized Coefficients } & Standardized Coefficients & Sig. \\
\cline { 2 - 5 } & B & Std. Error & Beta & -0.550 \\
Constant Loan Portfolio & -4.255 & 7.736 & & 0.593 \\
Diversification & 1.421 & 0.570 & 0.601 & 2.493 \\
\hline
\end{tabular}

Dependent Variable: Non-Performing Loans.

The overall model linking Loan Portfolio Diversification and the level of NPLs was thus fitted as follows:

$$
\mathrm{Y}=-4.255+1.42 \mathrm{D}
$$

Table 3 indicates that the Intercept term was -4.255 . This implies that when Loan Portfolio Diversification is Zero the level of NPLs would be zero. However the value of the intercept term was found to be statistically insignificant $(\mathrm{t}=$ $0.550, \mathrm{p}=0.593>0.05)$. The beta coefficient of Loans Portfolio Diversification was 1.421. Thus the model predicted that for every unit increase in Loan Portfolio Diversification, the level of NPLs would increase with 1.421 units after controlling for other variables in the model. It was found that loans advanced with this Portfolio Diversification had significant effect on the level of NPLs $(t=2.493$, $\mathrm{p}=0.030<0.05$ ). The low risk level of loan repayment could be attributed to the risk diversification resulting from advancing loan with different products in the loan portfolio. This was in line with [23] who found that the effective loan portfolio management had a direct influence on the profitability of the banks and SACCOs in Kenya. This was because banks and SACCOs depend on interest income as their revenue.

The Traditional banking theory also argues that banks should diversify their credit portfolio, given that through the expansion of their credit lines to new sectors, the bank's probability of default would reduce [16]. The idea was that due to asymmetric information, diversification would reduce financial intermediation costs.

\subsection{Loan Pricing and the Level of NPLs for SACCOs}

The study sought to establish the strength and magnitude of the relationship between Loan Pricing and the level of NPLs. The results are indicated in Table 4. The cause- effect relationship between Loan Pricing and the Level of NPLs was also analyzed and the results are indicated in Table 5.

Table 4. Test for Significance of the Model for Objective Two.

\begin{tabular}{|c|c|c|c|c|c|c|}
\hline \multirow{2}{*}{$\mathbf{R}$} & \multirow{2}{*}{$\mathbf{R 2}$} & \multirow{2}{*}{ Adjusted R2 } & \multirow{2}{*}{ Std. Error of the Estimate } & \multicolumn{3}{|l|}{ Change Statistics } \\
\hline & & & & R Square Change & F Change & Sig. Change \\
\hline 0.804 & 0.647 & 0.294 & $9,197,460$ & 0.647 & 1.834 & 0.261 \\
\hline
\end{tabular}

Predictors: (Constant), 0-12\%, 19\% - 36\%, 13\% - 18\%, 37\%- 120\%, above 120\%, Dependent Variable: Non-Performing Loans

Table 4 indicates that the correlation coefficient $(\mathrm{R})$ is 0.804 indicating that there was a positive strong correlation between the Loan Pricing and the level of NPLs. The $\left(\mathrm{R}_{2}\right)$ was 0.647 indicating that $64.7 \%$ of the variation in the level of NPLs was explained by the Loan Pricing while $35.3 \%$ were explained by other factors outside the model. From the results of Multiple linear regression analysis, it was found that the overall model was insignificant $(\mathrm{F}=1.834$, $p=0.261<0.05)$. Thus, the null hypothesis that Loan Pricing has no significance effect on the level of NPLs was accepted.

Table 5. Interest Rate and the Level of NPLs Statistics.

\begin{tabular}{|c|c|c|c|c|c|}
\hline \multirow{2}{*}{ Variable } & \multicolumn{2}{|c|}{ Unstandardized Coefficients } & \multirow{2}{*}{ Standardized Coefficients } & \multirow{2}{*}{$\mathbf{T}$} & \multirow{2}{*}{ Sig. } \\
\hline & B & Std. Error & & & \\
\hline (Constant) & $12,271,506$ & $6,974,760$ & & 1.759 & 0.139 \\
\hline $0-12 \%$ & -0.576 & 0.278 & -0.771 & -2.070 & 0.093 \\
\hline $13-18 \%$ & -0.047 & 0.022 & -2.676 & -2.178 & 0.081 \\
\hline $19-36 \%$ & 0.025 & 0.049 & 0.412 & 0.522 & 0.624 \\
\hline $37-120 \%$ & 0.643 & 0.397 & 3.111 & 1.620 & 0.166 \\
\hline Above $120 \%$ & 1.462 & 0.709 & 5.055 & 2.064 & 0.094 \\
\hline
\end{tabular}

Dependent Variable: Non-Performing Loans 
The overall model linking Loan Pricing and the level of NPLs was thus fitted as follows:

$$
\mathrm{Y}=12,271,506-0.576 \mathrm{I}_{1}-0.047 \mathrm{I}_{2}+0.025 \mathrm{I}_{3}+0.643 \mathrm{I}_{4}+1.462 \mathrm{I}_{5}
$$

Table 5 indicates that the Intercept term was Ksh. 12,271,506. This implies that when Loan price is Zero the level of NPLs would be equal to Ksh. 12,271,506. However, the value of the intercept term was found to be statistically insignificant $(\mathrm{t}=1.759, \mathrm{p}=0.139>0.05)$. The beta coefficient of Loans advanced at a rate of $0-12 \%$ range was -0.576 . Thus the model predicted that for every unit increase in loan advanced in this range, the level of NPLs would decrease with 0.576 units after controlling for other variables in the model. It was found that loans advanced at a rate of $0-12 \%$ range had no significant effect on the level of NPLs $(\mathrm{t}=-2.070$, $\mathrm{p}=0.093>0.05)$. The beta coefficient of Loans advanced at a rate of $13-18 \%$ range was -0.047 . Thus the model predicted that for every unit increase in loan advanced in this range, the level of NPLs would decrease with 0.047 units after controlling for other variables in the model. It was found that loans advanced at a rate of $13-18 \%$ range had no significant effect on the level of NPLs $(\mathrm{t}=-2.178, \mathrm{p}=0.081>0.05)$. The beta coefficient of Loans advanced with Loan Price 19-36 \% range was 0.025 . Thus the model predicted that for every unit increase in loan advanced in this range, the level of NPLs would increase with 0.025 units after controlling for other variables in the model. It was found that loans advanced at a rate of $19-36 \%$ range had no significant effect on the level of NPLs $(t=0.522, p=0.624>0.05)$. The beta coefficient of Loans advanced with Tenure $37-120 \%$ range was 0.643 . Thus the model predicted that for every unit increase in loan advanced in this range, the level of NPLs would increase with 0.643 units after controlling for other variables in the model. It was found that loans advanced at a rate of 37-120\% range did not have significant effect on the level of NPLs $(t=1.620$, $\mathrm{p}=0.166>0.05$ ). The beta coefficient of Loans advanced at a rate above $120 \%$ was 1.462 . Thus the model predicted that for every unit increase in loan advanced in this range, the level of NPLs would increase with 1.462 units after controlling for other variables in the model. It was found that loans advanced at a rate above $120 \%$ had no significant effect on the level of NPLs $(\mathrm{t}=2.064, \mathrm{p}=0.094<0.05)$. This was in line with a study conducted by [19] that focused on macroeconomic and bank specific factors influencing NPLs and their effect in GCC Banking system. After a comprehensive analysis they found that high interest rates increase NPLs but the relationship was not statistically significant.

\subsection{Loan Tenure and the Level of NPLs for SACCOs}

The study sought to establish the strength and magnitude of the relationship between Loan Tenure and the level of NPLs. The results are indicated in Table 11. The cause- effect relationship between Loan Tenure and the Level of NPLs was also analyzed and the results are indicated in Table 6.

Table 6. Test for Significance of the Model for Objective Three.

\begin{tabular}{|c|c|c|c|c|c|c|}
\hline \multirow{2}{*}{$\mathbf{R}$} & \multirow{2}{*}{$\mathbf{R}^{2}$} & \multirow{2}{*}{ Adjusted $\mathbf{R}^{2}$} & \multirow{2}{*}{ Std. Error of the Estimate } & \multicolumn{3}{|l|}{ Change Statistic } \\
\hline & & & & R Square Change & F Change & Sig. Change \\
\hline 0.577 & 0.338 & 0.333 & $13,008,366$ & 0.333 & 3.498 & 0.047 \\
\hline
\end{tabular}

Predictors: Constant, 0 -12 months, 13-24 months, 49- 60 months, 25- 48 months and above 60 months

Dependent Variable: Non-Performing Loans

Table 6 indicates that the correlation coefficient $\mathrm{R}$ is 0.577 indicating that there was a positive moderate correlation between Loan tenure and the level of NPLs. R2 was 0.338 indicating that $33.8 \%$ of the variation of the level of NPLs was explained by Loan Pricing while $66.2 \%$ were explained by other factors outside the model. From the results of multiple linear regression analysis, it was found that the overall model was significant $(\mathrm{F}=3.498, \mathrm{p}=0.476<0.05)$. Thus, the null hypothesis that Loan Tenure has no significance effect on the level of NPLs was rejected.

Table 7. Loan Tenure and NPLs Statistics.

\begin{tabular}{lllll}
\hline \multirow{2}{*}{ Variables } & \multicolumn{2}{l}{ Unstandardized Coefficients } & Standardized Coefficients & Sig. \\
\cline { 2 - 3 } & B & Std. Error & Beta & 0.669 \\
\hline Constant & $5,275,283$ & $1,161,1039$ & -0.677 & 0.454 \\
$0-12$ months & -0.228 & 0.005 & 0.361 & -4.569 \\
$13-24$ months & 0.058 & 0.013 & -0.018 & 4.461 \\
$25-48$ months & 0.000 & 0.047 & 0.318 & 0.009 \\
49- 60 months & 0.022 & 0.014 & -0.677 & 0.047 \\
Above 60 months & 0.024 & 0.027 & 0.122 & 0.020 \\
\hline
\end{tabular}

Dependent Variable: Non-Performing Loans

The overall model linking Loan Tenure and the level of NPLs was thus fitted as follows:

$$
\mathrm{Y}=5,275,283-0.228 \mathrm{~T} 1+0.058 \mathrm{~T} 2+0.00 \mathrm{~T} 3+0.022 \mathrm{~T} 4+0.22 \mathrm{~T} 5
$$

Table 7 indicates that the Intercept term was Ksh. 5,275,283. This implies that when Loan Tenure is Zero the 
level of NPLs would be equal to Ksh. 5,275,283. However, the value of the intercept term was found to be statistically insignificant $(\mathrm{t}=0.454, \mathrm{p}=0.669>0.05)$. The beta coefficient of Loans advanced with a repayment period between 0-12 months was 0.228 . Thus the model predicted that for every unit increase in loan advanced in this range, the level of NPLs would decrease with 0.228 units after controlling for other variables in the model. It was found that loans advanced with a repayment period between 0-12 months had significant effect on the level of NPLs ( $t=-04569$, $\mathrm{p}=0.041<0.05$ ). The beta coefficient of Loans advanced with a repayment period between 13-24 months was 0.058 . Thus the model predicted that for every unit increase in loan advanced in this range, the level of NPLs would increase with 0.058 units after controlling for other variables in the model. It was found that loans advanced with a repayment period between 13-24 months had significant effect on the level of NPLs $(t=4.461, p=0.047<0.05)$. The beta coefficient of Loans advanced with a repayment period between 25-48 months was zero. Thus the model predicted that for every unit increase in loan advanced in this range, the level of NPLs would increase with zero units after controlling for other variables in the model. It was found that loans advanced with a repayment period between 25-48 months range did not have significant effect on the level of NPLs $(t=0.009, p=0.993>0.05)$. The beta coefficient of Loans advanced with a repayment period between 49-60 months range was 0.022 . Thus the model predicted that for every unit increase in loan advanced in this range, the level of NPLs would increase with 0.022 units after controlling for other variables in the model. It was found that loans advanced with a repayment period between 49-60 months had significant effect on the level of NPLs $(t=1.572, p=0.020<0.05)$. The beta coefficient of Loans advanced with a repayment period between above 60 months was 0.22 . Thus the model predicted that for every unit increase in loan advanced in this range, the level of NPLs would increase with 0.22 units after controlling for other variables in the model. It was found that loans advanced with a repayment period between above 60 months had significant effect on the level of NPLs $(\mathrm{t}=0.815$, $\mathrm{p}=0.039<0.05$ ). This was in line with Hannah et al., (2011) who observed that members are not satisfied with the shorter repayment period, and that pegging loans on deposits was denying member's money which they had ability to pay.

\subsection{Loan to Shareholders' Equity and the Level of NPLs for SACCOS}

The study sought to establish the strength and magnitude of the relationship between Loan to Shareholders' Equity and the level of NPLs. The results are indicated in Table 8. The cause-effect relationship between Loan to Shareholders' Equity and the Level of NPLs was also analyzed and the results are indicated in Table 9.

Table 8. Test for Significance of the Model for Objective Four.

\begin{tabular}{|c|c|c|c|c|c|c|}
\hline \multirow{2}{*}{$\mathbf{R}$} & \multirow{2}{*}{$\mathbf{R 2}$} & \multirow{2}{*}{ Adjusted R2 } & \multirow{2}{*}{ Std. Error of the Estimate } & \multicolumn{3}{|l|}{ Change Statistics } \\
\hline & & & & R Square Change & F Change & Sig. Change \\
\hline 0.522 & 0.273 & 0.207 & 9.574 & 0.273 & 4.123 & 0.047 \\
\hline
\end{tabular}

Predictors: (Constant), Loans to Shareholders' Equity Ratio

Dependent Variable: Non-Performing Loans

Table 8 indicates that the correlation coefficient (R), is 0.522 indicating that there was a positive moderate correlation between the Loan to Shareholders Equity and the NPLs. The $\left(\mathrm{R}_{2}\right)$ was 0.273 implying that $27.3 \%$ of the variation in the level of NPLs was explained by the Loan to Shareholders Equity while $72.7 \%$ were explained by other factors outside the model. From the results of simple linear regression analysis, it was found that the overall model was significant $(\mathrm{F}=4.123, \quad \mathrm{p}=0.047<0.05)$. Thus, the null hypothesis that Loan to Shareholders' Equity has no significance effect on the level of NPLs was rejected.

Table 9. Loan to shareholders' Equity and NPLs Statistics.

\begin{tabular}{llllll}
\hline \multirow{2}{*}{ Variables } & \multicolumn{2}{l}{ Unstandardized Coefficients } & Standardized Coefficients & \multirow{2}{*}{ T } & \multirow{2}{*}{ Sig. } \\
\cline { 2 - 5 } & B & Std. Error & Beta & 1.068 & 0.308 \\
(Constant) & 5.359 & 5.017 & & 2.306 & 0.047 \\
Loan to Shareholders' Equity & 3.237 & 1.404 & 0.522 & & \\
Ratio & & & & & \\
\hline
\end{tabular}

Dependent Variable: Non-performing Loans

The overall model linking Loan to Shareholders' Equity and the level of NPLs was thus fitted as follows:

$$
\mathrm{Y}=5.359+3.237 \mathrm{E}
$$

Table 9 indicates that the Intercept term was 5.359. This implies that when Loan to Shareholders Equity is Zero the level of NPLs would be equal to Ksh. 5.359. However the value of the intercept term was found to be statistically insignificant $(\mathrm{t}=1.068, \mathrm{p}=0.308>0.05)$. The beta coefficient of Loans to Shareholders Equity was 3.237. Thus the model predicted that for every unit increase in loan advanced in this range, the level of NPLs would increase with 3.237 units after controlling for other variables in the model. It was found that loan to Shareholders Equity had significant effect on the level of NPLs $(t=2.306, p=0.047<0.05)$. 


\subsection{Size of Loan and Level of NPLs for SACCOS}

The study sought to establish the strength and magnitude of the relationship between Size of Loan and the level of NPLs. The results are indicated in Table 10. The cause- effect relationship between Size of Loan and the Level of NPLs was also analyzed and the results are indicated in Table 11.

Table 10. Test for Significance of the Model for Objective Five.

\begin{tabular}{|c|c|c|c|c|c|c|}
\hline \multirow{2}{*}{$\mathbf{R}$} & \multirow{2}{*}{$\mathbf{R}^{2}$} & \multirow{2}{*}{ Adjusted R ${ }^{2}$} & \multirow{2}{*}{ Std. Error of the Estimate } & \multicolumn{3}{|l|}{ Change Statistics } \\
\hline & & & & R Square Change & F Change & Sig. Change \\
\hline 0.947 & .896 & 0.792 & $3,926,187$ & 0.896 & 8.613 & 0.017 \\
\hline
\end{tabular}

Predictors: (Constant), Ksh. 0-100,000, 100,001-250,000, 250,001-500,000, 500,001-1,000,000, above 1,000,000

Dependent Variable: Non-Performing Loans

Table 9 indicates that the correlation coefficient (R) is 0.947 indicating that there was a positive strong correlation between the loan size and the level of NPLs. $\mathrm{R}^{2}$ was 0.896 implying that $89.6 \%$ of the variation in the level of NPLs was explained by the Size of Loan while $13.4 \%$ were explained by other factors outside the model. From the results of Multiple linear regression analysis, it was found that the overall model was significant $(\mathrm{F}=8.613, \mathrm{p}=0.017<0.05)$. Thus, the null hypothesis that Size of Loan has no significance effect on the level of NPLs was rejected.

Table 11. Loan Size and the level of NPLs Statistics.

\begin{tabular}{llllll}
\hline \multirow{2}{*}{ Variable Ksh. } & \multicolumn{2}{l}{ Unstandardized Coefficients } & Standardized Coefficients & \multirow{2}{*}{ T } & \multirow{2}{*}{ Sig. } \\
\cline { 2 - 4 } & B & Std. Error & Beta & 0.437 & 0.680 \\
Constant & $1,001,379$ & $2,291,649$ & & 0.562 & 0.598 \\
$0-100,000$ & 0.009 & 0.015 & 0.261 & 0.680 & 0.527 \\
$100,001-250,000$ & 0.011 & 0.017 & 0.306 & 0.933 & 0.393 \\
$250,001-500,000$ & 0.004 & 0.004 & 0.157 & 4.954 & 0.004 \\
$500,001-1,000,000$ & 0.028 & 0.006 & 1.249 & -1.720 & 0.146 \\
Above $1,000,000$ & -0.041 & 0.024 & -0.472 & \\
\hline
\end{tabular}

Dependent Variable: Non-Performing Loans

The overall model linking Size of Loan and the level of NPLs was thus fitted as follows:

$$
\mathrm{Y}=1,001,379+0.009 \mathrm{~S}_{1}+0.011 \mathrm{~S}_{2}+0.004 \mathrm{~S}_{3}+0.028 \mathrm{~S}_{4}-0.041 \mathrm{~S}_{5}
$$

Table 11 indicates that the Intercept term was Ksh. 1,001.379. This implies that when Size of Loan is Zero the level of NPLs would be equal to Ksh. 1,001,379. However the value of the intercept term was found to be statistically insignificant $(\mathrm{t}=0.437, \mathrm{p}=0.680>0.05)$. The beta coefficient of Loans advanced in Ksh. 0-100,000 range was 0.09 . Thus the model predicted that for every unit increase in loan advanced in this range, the level of NPLs would increase with 0.09 units after controlling for other variables in the model. It was found that loans advanced in Ksh. 0-100,000 range did not have significant effect on the level of NPLs $(t=0.562$, $\mathrm{p}=0.598>0.05$ ). The beta coefficient of Loans advanced in Ksh. 100,001-250,000 range was 0.011. Thus the model predicted that for every unit increase in loan advanced in this range, the level of NPLs would increase with 0.011 units after controlling for other variables in the model. It was found that loans advanced in Ksh. 100,001-250,000 range did not have significant effect on the level of NPLs $(\mathrm{t}-0.680$, $\mathrm{p}=0.527>0.05$ ). The beta coefficient of Loans advanced in Ksh. 250,001-500,000 range was 0.004. Thus the model predicted that for every unit increase in loan advanced in this range, the level of NPLs would increase with 0.004 units after controlling for other variables in the model. It was found that loans advanced in Ksh.250,001-500,000 range did not have significant effect on the level of NPLs ( $t=0.933$, $p=0.393>0.05$ ). The beta coefficient of Loans advanced in
Ksh. 500,001-1,000,000 range was 0.028. Thus the model predicted that for every unit increase in loan advanced in this range, the level of NPLs would increase with 0.028 units after controlling for other variables in the model. It was found that loans advanced in Ksh. 500,001-1,000,000 range had a significant effect on the level of NPLs $(t=4.954$, $\mathrm{p}=0.004<0.05$ ). The beta coefficient of Loans advanced above Ksh. 1,000,000 was -0.041 . Thus the model predicted that for every unit increase in loan advanced in this range, the level of NPLs would decrease with 0.041 units after controlling for other variables in the model. It was found that loans advanced above Ksh. 1,000,000 did not have significant effect on the level of NPLs $(t=-1.720$, $\mathrm{p}=0.146>0.05$ ). Size of Loan in Ksh. 500,001-1,000,000 range and above Ksh. 1,000,000 are not like to be defaulted because they are advanced to borrowers with stable financial base hence able to service their loans. This is in line with [53] who found out that there existed a negative relationship between loans of big amount and NPLs and argue that bigger size loans allowed for more opportunities of loan diversification.

\section{Summary, Conclusions, and Recommendations}

\subsection{Summary of Findings}

The general objective of the study was to determine the effect of Loan Portfolio Characteristics on the level of NPLs for SACCOs in Kirinyaga County, Kenya. This was achieved 
by determining the effect of Loan Portfolio Diversification, Loan Pricing, Loan Tenure, and Loan to Shareholders' Equity and Size of Loan on the level of NPLs.

The overall model predicting the relationship between Loan Portfolio Diversification and NPLs for SACCOs was found to be statistically significant $(\mathrm{F}=6.214$ and $\mathrm{p}=0.03<0.05$ ). Thus, the null hypothesis that Loan Portfolio Diversification has no significance effect on the level of NPLs was rejected. The model had $\mathrm{R}_{2}=0.361$ indicating that $36.1 \%$ of the variations of NPLs were explained by Loan Portfolio Diversification while $63.9 \%$ of the variations were explained by other factors not included in the model. Further the overall model predicting the relationship between Loan Pricing and NPLs for SACCOs was found not to be statistically significant $(\mathrm{F}=1.834$ and $\mathrm{p}=0.261>0.05)$. Thus, the null hypothesis that Loan Pricing has no significance effect on the level of NPLs was accepted. The model had $\mathrm{R}_{2}=0.647$ indicating that $64.7 \%$ of the variations of NPLs were explained by Loan Portfolio Pricing while $35.3 \%$ of the variations were explained by other factors not included in the model. In addition the overall model predicting the relationship between Loan Tenure and NPLs for SACCOs was found to be statistically significant $(\mathrm{F}=3.498$ and $\mathrm{p}=0.0476<0.05$ ). Thus, the null hypothesis that Loan Tenure has no significance effect on the level of NPLs was rejected. The model had $\mathrm{R}_{2}=0.338$ indicating that $33.8 \%$ of the variations of NPLs were explained by Loan Tenure while $66.2 \%$ of the variations were explained by other factors not included in the model. Also considered was the overall model predicting the relationship between Loan to Shareholders' Equity and NPLs for SACCOs which was found to be statistically significant $(\mathrm{F}=4.123$ and $\mathrm{p}=0.047<0.05)$. Thus, the null hypothesis that Loan to shareholders' has no significance effect on the level of NPLs was rejected. The model had $\mathrm{R}_{2}=0.273$ indicating that $27.3 \%$ of the variations of NPLs were explained by Loan to Shareholders' Equity while $72.7 \%$ of the variations were explained by other factors not included in the model. Finally the overall model predicting the relationship between Size of Loan and NPLs for SACCOs was found to be statistically significant $(\mathrm{F}=8.613$ and $\mathrm{p}=0.017<0.05)$. Thus, the null hypothesis that Size of Loan has no significance effect on the level of NPLs was rejected. The model had $\mathrm{R}_{2}=0.896$ indicating that $89.6 \%$ of the variations of NPLs were explained by Size of Loan while $27.3 \%$ of the variations were explained by other factors not included in the model

\subsection{Conclusions}

Conclusion was based on the main findings of the study in reference with specific objectives. The study established that Loan Portfolio Diversification has a significant effect on the level of NPLs for SACCOs. SACCOs with high level of loan products are likely to reduce the level of NPLs. This is because of reduction of risk as a result of diversification. Further, it was established that Loan Pricing had no significant effect on the level of NPLs for SACCOs. Thus, Loan Pricing did not affect the level of NPLs. This was probably because borrowers would default repaying the loan regardless of the interests charged as a result of individual reluctance to repay. A borrower who is unwilling to repay would not remit the repayment amount even if loan price is adjusted in ones favor. It was also established that Loan Tenure had a significant effect on NPLs for SACCOs.

Thus SACCOs issuing loans with long repayment period were likely to have high NPLs as compared with those issuing short term loans. This is because customers taking long term are more likely to be faced by unforeseen eventualities making it difficult to continue servicing their loans. Further it was established that Loan to Shareholders' Equity had a significant effect on NPLs of SACCOs hence SACCOs with a high ratio of Loan to Shareholders' Equity were less likely to have high level of NPLs. This was probably because customers had confidence with SACCOs with a high ratio of Loan to Shareholders' Equity and would not want to contribute to their failure. It was also established that Size of Loan had a significant effect on NPLs of SACCOs hence; SACCOs that issue large loans were less like to have a big number of defaulters. This was probably because customers who borrow huge sums of money are financially stable hence they did not have problems with servicing their loans.

\section{Recommendations}

Based on the finding of the study the following recommendations are made:

i. The SACCOs should diversify their loan portfolio by advancing loan of different products. This will enable them reduce NPLs since each borrower will consider borrowing the loan that is most convenient to service.

ii. Lenders should not concentrate much on making decision on interest rate adjustment. This is because each borrower will borrow at the loan price he considers appropriate depending on the urgency of the funds.

iii. The lenders should consider adjusting the loan repayment period appropriately. This is because most borrowers prefer a longer repayment period though the cost of borrowing could be high. However SACCOs should come up with ways of overcoming challenges of unforeseen eventualities which could make customers unable to service their loans.

iv. The SACCOs should consider increasing the ratio of Loan to Shareholder equity to win public confidence and have a strong asset base. This also maintains the cost of running the SACCOs as low as possible as compared to running the SACCOs with a high leverage ratio.

v. SACCOs should enhance advancing loans of different sizes because different customers have different borrowing capability. This will ensure that they optimize on the amount advanced hence increase their income. 


\section{Suggestion for Further Research}

The researcher suggests the following areas for further research;

i. The effect of Loan Portfolio Diversification on the level of NPLs for SACCOs in Kenya.

ii. The effect of NPLs on the level of Profitability of SACCOs in Kenya

\section{References}

[1] Acharya, V., Hasan, I., Saunders (2004), Should Banks Be Diversified? Evidence from Individual Bank Loan Portfolios. Working Paper, London Business School, London, forthcoming in: Journal of Business (July 2006). Bass Inc. Publication.

[2] Alton R. G and Hazen J. H (2001), “As Economy Flounders, Do We See A Rise in Problem Loans?" Federal Reserve Bank of St. Louis.

[3] Bailey,T. (2001). Applying International Best Practices to South Africa's SACCOs: Published Dissertation. South Africa: De Mont Fort University.

[4] Batra, S. (2003). Developing the Asian Markets for NonPerforming Assets; Developments in India, 3rd Forum on Asian Insolvency Reform, Seoul, Korea.

[5] Bernstein, D. (1996). Asset Quality and Scale economie in Banking: Journal of economics and business, 48:157-166.

[6] Bexley J. B and Nenninger S (2012), Financial Institutions and the Economy. Journal of Accounting and Finance, 12(1) 2012.

[7] BIS. Measuring and Controlling Large Credit Exposures. Basel Committee on Banking Supervision.

[8] Brennan, M. J. (1971). Capital Market Equilibrium with Divergent Borrowing and Lending Rates. The Journal of Financial and Quantitative Analysis, 6(5), 1197-1205.

[9] Business Dictionary (2014). Loa Portfolio. Retrieved from: http://www.businessdictionary.com/definition/loanportfolio.html\#ixzz2wb2vY2OU (Accessed 21/03/2014).

[10] Central Bank. (2003). Bank Supervision Annual Report. Nairobi: Central Bank. Central Bank. (2008). Bank Supervision Annual Report. Nairobi: Central Bank. Central Bank. (2010). Bank Supervision Annual Report. Nairobi: Central Bank. Chang, S. J., (1999) Business Group and Social Welfare in emerging Markets.

[11] Chen, M. H., Kim, W. G. and Kim, H. J. (2005). Macro and Non-Macro Explanatory.

[12] Chijoriga, M. M. (2007), “Application of credit scoring and financial distress prediction models to commercial banks" lending": The case of Tanzania.

[13] Demsetz, H. (1997) "The Primacy of Economics: An Explanation of the Comparative Success of Economics in the Social Sciences".

[14] Derrick, T. H., Peterson, L., \& Premschak, C. (1998). Loan Portfolio Management. Retrieved from: http://www.fca.gov/Download/lpmfortheweb.pdf.
[15] DeYoung, R., and Rice, T. (2004). How do banks make money? The Fallacies of Fee Income.

[16] Diamond D. W. (1984). Financial Intermediation and Delegated Monitoring, Review of Financial Studies, 51, 393 414.

[17] Diamond, D. W., \& Rajan, R. G. (1998). Liquidity Risk, Liquidity Creation and Financial Fragility: A Theory of Banking, Mimeo, University of Chicago.

[18] Emmanuelle, N. Y. S., (2003). A European Study of Bank Interest Margins.

[19] Espinoza R., Prasad A. and Williams O., (2010). NonPerforming Loans in the GCC. Banking and Their Macroeconomic Effect. IMF Working Paper, Vol., pp1- 24, 2010 Available at SSRN: http:// ssrn. Com/abstract $=1750712$.

[20] Factors of Chinese Hotel Stock Returns. International Journal of Hospitality Management, 24,243-258.

[21] Farm Credit Administration (FCA 1998) Loan Portfolio Management.

[22] French, C. W. (2003). The Treynor Capital Asset Pricing Model. Journal of Investment Management 1 (2): 60-72.

[23] Gehr, A. (1975). Some Tests of the Arbitrage Pricing Theory, Journal of Midwest Finance Association, pp. 91-105.

[24] George, G. E., Miroga, J. B., Ngaruiya, N. W., Mindila, R., Nyakwara, S., Mobisa, M. J., Ongeri J., Mandere, E. N., \& Moronge, M. O. (2013). An Analysis of Loan Portfolio Management on Organization Profitability: Case of Commercial Banks in Kenya. Research Journal of Finance and Accounting, 4(8), 24-35.

[25] Goldstein, M., \& Turner, P., (1996). Banking crises in emerging Economies: Origins and policy options, Bank for International Settlements (BIS) Economic Papers No. 46: Available at wb-cu.car.chula.ac.th. Accessed April 12, 2010.

[26] Gorter and bloem (2002) Non-Performing loans are mainly caused by an inevitable.

[27] Hannah, K., Gekara, M., \& Joseph, M. (2013). Effect of operating costs on the financial performance of SACCOs in the banking sector in Kenya. Prime Journal of Business Administration and Management (BAM) ISSN: 2251- 1261. Vol. 4(2), ppp0*. 1359-1363, retrieved from, www.primejournal.org/BAM.

[28] Hennie V. G (2003), Analyzing and Managing Banking Risk: A Framework for Assessing Corporate Governance and Financial Risk, 2nd Edition, Washington DC: World Bank Publications.

[29] Hennie, V. G and Sonja,B. (2009): Analyzing banking risk.

[30] Hirtle, B. J, and K. J. Stiroh, 2007. The return to retail and the performance of US banks. Journal of Banking and Finance 31: 1101-1133.

[31] Kathuri, N. J. \& Pals, D. A. (1993). Introduction to Educational Research. Njoro, Kenya: Egerton University Education Media Centre.

[32] Kombo, K., \& Tromp, D. (2006). Project and Thesis writing: An introduction. Paulines publications Africa: Nairobi Kenya. 
[33] Kothari, C. R. (2004). Research methodology: Methods\& Techniques, New Delhi India: New Age international (p) limited. 2nd E. D.

[34] kwan, S. H., and E. S. Laderman. (1999). "On the portfolio effects of financial convergence: A review of the literature." Fed. Reserve Bank San Francisco Rev. 2, 18-31.

[35] Laeven, L. and R. Levine. (2007). "Is there a diversification discount in financial conglomerates?" J. Finan. Econ. 85, 331367.

[36] Maina, J. M. (2003). Relationship between Credit Risk Management Practices and Financial Performance of Microfinance Institutions in Kenya. Unpublished MBA Project. University of Nairobi.

[37] Markowitz (1952), Portfolio Selection. Journal of finance, Volume 7, issue 1, p 77-91.

[38] McNulty, J., Akhigbe, A. \&Verbrugge, J. (2001). Small Bank loan quality in a Deregulated Environment: The information advantage hypothesis. Journal of Economics and Business, 53, 325-39.

[39] Micco, A., Panizza (2004). "Bank ownership and performance. “ Research Department working paper 518. Washington, DC united states: InterAmerica Development bank, Research Department.

[40] Michael, JN., Vasanthi, G., \& Selvaraju, R. (2006). Effect of Non-Performing Assets on Operational Efficiency of CentralCooperative Banks, Indian Economic Panorama, Vol. 16(3). 33-39.

[41] Mudibo, K. E. (2005 November). Corporate Governance in Cooperatives: the East African Experience. Report Presented at the 3rdPan- Afric Consultative Forum on Corporate Governance, Dakar: Senegal.

[42] Mugenda. O and Mugenda A. (2003); Research methods: Quantitative and Qualitative.

[43] Myers, S. (2000) The Determinants of Corporate Borrowing, Journal of Financial Economics, 5, 147-175.

[44] Ngugi, R. W., (2001). An Empirical Analysis of Interest Rate Spread in Kenya. African Economic Research Consortium, Research Paper 106. number of wrong economic decisions by individuals IMF working paper 2003. No. 10(3).

[45] Office of Comptroller of the Currency (OCC 1998). Comptroller's Handbook (1998): Loan Portfolio Management.

[46] Pelrine, R., \& Kabatalya, O. (2005). Savings Habits, Needs and Priorities in Rural Uganda. Kampala: USAID/ Rural SPEED.

[47] Rhyne, E., (2002). The Yin and Yang of Microfinance: Reaching the Poor.
[48] Roll, R., and Ross, S. (1980). An empirical investigation of the arbitrage pricing theory. Journal of Finance 35: 10731103.

[49] Ross, S. A. (1976). The Arbitrage Theory of Capital Asset Pricing. Journal of Economic Theory, 13(3), 341-360.

[50] SACCO Societies Regulatory Authority (SASRA) (2012). Sacco Supervision Report: Deposit Taking SACCOs. In house Publication.

[51] SACCO Societies Regulatory Authority (SASRA) (2013). Sacco Supervision Report: Deposit Taking SACCOs. In house Publication.

[52] SACCO Societies Regulatory Authority (SASRA) (2014). Sacco Supervision Report: Deposit Taking SACCOs. In house Publication.

[53] Sala, V. \& Saurina, J. (2002), Credit Risk in Two Institutional regimes: Spanish. Sambasivam, Y., \& Biruk, A. (2013) Financial Performance analysis of GOHE Co- operatives Savings and Credit Union in Bure Woreda, Ethiopia. International journal research journal of economics and business studies. Debre Markos University, Debre Markos, Ethiopia.

[54] Shao, A. T. (1999): Marketing Research. Ohio: SouthWestern College Publishing. Sorge, Marco (2004). "Stresstesting financial systems: an overview of current mythologies." BIS Working Papers No. 165, December.

[55] Stiroh, K. J. (2004b). "Dom Community Banks Benefit from Diversification?" J. Finan. Services Res. 25, 135-160.

[56] Stiroh, K. J. (2006). "A portfolio view of banking with interest and noninterest activities." J. Money, Credit, Banking 38, 1351-1362.

[57] The International Association of Credit Portfolio Managers (IACPM 2005). Sound Practices in Credit Portfolio Management. Retrieved from: http://web.iacpm.org/library/public documents/IACPMSound Practices.pdf. (Accessed 20/03/2014).

[58] Tirapat, S., (1999). Solutions of banking crisis, available: www. Cu.car. Chula.ac.th.Default bank Loans. Published in Bank parikrama, Retriveed 12 February 2010.

[59] Wheelock, D. and P. Wilson. (2002). "Why do banks disappear: the determinants of U. S. bank failures and acquisitions?" Rev. Econ. Statist. 82, 127-138.

[60] Wise Geek (2014). What Is Credit Portfolio Management? Retrieved from: http://www.wisegeek.com/what-is-creditportfolio-management.htm. (Accessed on 21/03/2014).

[61] World Council of Credit Unions (WOCCU) (2009) Statistical report, World Council of Credit Unions, Washington D.C. 